DURNAI, RIS'II
(Rekayasa Sistem dan Teknologi Informasi)
Vol.3 No.3 (2019) $389-394$

\title{
Prototype Alat Pengendali Lampu dengan Perintah Suara menggunakan Arduino Uno Berbasis Web
}

\author{
Nurul Isna Ganggalia ${ }^{1}$, Apri Junaidi ${ }^{2}$, Fahrudin Mukti Wibowo ${ }^{3}$ \\ ${ }^{1,2,3}$ Teknik Informatika, Fakultas Teknik Industri dan Informatika, Institut Teknologi Telkom Purwokerto \\ ${ }^{1} 15102030 @$ st3telkom.ac.id, ${ }^{2}$ aprijunaidi@ittelkom-pwt.ac.id, ${ }^{3}$ fahrudin@ittelkom-pwt.ac.id
}

\begin{abstract}
The use of electric power for lights often less considered, a lot of lights are on continuously even though it's not used. As a result, a lot of electricity is wasted. This motivated researchers to create innovations of creating a light control system. The light controller system is designed to simplify and benefit the user. For this reason, researchers make light controllers on the web use voice commands that can be done anywhere and anytime using the internet. Making a prototype of a light control system with voice commands utilizes speech to text on the Web Speech API that converts sound into text, then it will be processed into a command of light controllers by the Arduino Uno microcontroller. The researcher used the prototype development method, where through 3 stages starting from Listen to Customer, Design and Building, and Test Drive Evaluations. The testing results are Internet speed and noise level affect the success rate on the use of light control using sound. At $9.9 \mathrm{Mbps}$ internet speed has a success rate of $86 \%$ with response time 2.01 second, while at internet speed 1.9 Mbps has a success rate of $65 \%$ with response time 2.50 second. At the noise level of $34.5 \mathrm{~dB}$ room has a success rate of $86 \%$ with response time 2.02 second, while the noise level of $62 \mathrm{~dB}$ has a success rate of $72 \%$ with response time 2.21 second.
\end{abstract}

Keywords : arduino uno, light control, prototype, speech, web.

\begin{abstract}
Abstrak
Penggunaan daya listrik akan lampu sering kali kurang diperhatikan, banyak lampu yang menyala terus menerus meskipun sudah tidak digunakan. Akibatnya banyak daya listrik yang terbuang percuma. Hal tersebut memotivasi peneliti untuk menciptakan inovasi dalam membuat sistem pengendali lampu. Sistem pengendali lampu dirancang untuk mempermudah dan menguntungkan pengguna. Untuk itu, peneliti membuat pengendali lampu pada web menggunakan perintah suara yang dapat dilakukan dimana saja dan kapan saja dengan memanfaatkan internet. Pembuatan prototype sistem pengendali lampu dengan printah suara memanfaatkan speech to text pada Web Speech API yang mengubah suara menjadi teks, lalu akan diproses menjadi perintah pengendali lampu oleh mikrokontroler Arduino Uno. Peneliti menggunakan metode pengembangan prototype, dimana melalui 3 tahapan yaitu dimulai dari Listen to Customer, Design and Building, dan untuk selanjutnya Test Drive and Evaluations. Hasil dari pengujian yaitu kecepatan Internet dan tingkat kebisingan mempengaruhi tingkat keberhasilan pada penggunaan kendali lampu menggunakan suara. Pada kecepatan internet 9.9 Mbps memiliki tingkat keberhasilan 86\% dengan waktu respon 2.01 detik, sedangkan pada kecepatan internet 1.9 Mbps memiliki tingkat keberhasilan 65\% dengan waktu respon 2.50 detik. Pada tingkat kebisingan ruang 34.5 dB memiliki tingkat keberhasilan sebesar $86 \%$ dengan waktu respon 2.02 detik, sedangkan pada tingkat kebisingan ruang $62 \mathrm{~dB}$ memiliki tingkat keberhasilan $72 \%$ dengan waktu respon 2.21 detik.
\end{abstract}

Kata kunci: arduino uno, pengendali lampu, prototype, suara, web..

(C) 2019 Jurnal RESTI

Diterima Redaksi : 05-08-2019 | Selesai Revisi : 05-11-2019| Diterbitkan Online : 09-11-2019 


\section{Pendahuluan}

Kebutuhan akan daya listrik merupakan kebutuhan yang vital bagi manusia. Kehidupan sehari-hari tidak dapat terlepas dari kebutuhan akan daya listrik. Banyak peralatan elektronik memerlukan daya listrik untuk dapat bekerja dengan baik sesuai dengan fungsinya. Namun penggunaan daya listrik itu sendiri sering kali kurang diperhatikan oleh pengguna. Banyak peralatan elektronik seperti lampu yang menyala terus menerus meskipun sudah tidak digunakan kembali. Akibatnya banyak daya listrik yang terbuang percuma. Penghematan akan daya listrik harus diperhatikan, tentunya agar alokasi anggaran tidak terbuang percuma. Pemerintah melalui menteri Energi dan Sumber Daya Mineral (ESDM) seringkali menghimbau masyarakat untuk menggunakan daya listrik secara bijak sehingga penggunaannya lebih hemat. Hal tersebut dapat
dilakukan apabila penggunaan akan daya listrik disamping menggunakan peralatan elektronik yang hemat energi juga dilakukan dengan pengendalian daya listrik sehingga lebih efektif dan efisien

Kemajuan ilmu pengetahuan dan teknologi memotivasi manusia untuk dapat menciptakan inovasi-inovasi dalam memudahkan pekerjaan manusia sehingga lebih menguntungkan, salah satunya adalah sistem Penelitian terhadap pengendalian peralatan elektronik pengendali lampu. Hal yang paling sering dilupakan menggunakan suara sudah banyak dilakukan. manusia ketika berada di luar rumah atau keluar rumah Diantaranya penelitian yang dilakukan oleh Dicky dengan keadaan terburu-buru salah satunya yaitu Andyka dan Moh Choiril Anwar, dengan judul manusia lupa untuk mematikan lampu [1]. Ketika lupa Rancang Bangun Aplikasi Android Pengendalian mematikan lampu saat keadaan sudah diluar rumah, Smarthome Menggunakan Perintah Suara. Hasil atau jauh dari rumah, manusia diharuskan melakukan penelitianmya berupa pengendalian lampu yang sebuah usaha yang membutuhkan tenaga dan waktu dilakukan melalui smartphone Android menggunakan untuk mematikan lampu rumah, akibatnya sering kali App Invertor dengan memanfaatkan komunikasi manusia kurang memperhatikan penggunaan daya Bluetooth. Jarak kontrol pada sistem tersebut $20 \mathrm{~m}$, listrik lampu.

Perkembangan teknologi yang dapat dimanfaatkan Penelitian mengenai Perancangan Aplikasi Voice sebagai media dalam meningkatkan efisiensi kerja Command Recognition Berbasis Android dan Arduino adalah internet, dengan adanya koneksi internet ini Uno ditulis oleh Akhmad Wahyu Dani, dkk. Hasil manusia dapat mengakses peralatan elektronik seperti penelitiannya berupa pengendalian lampu yang lampu ruangan dengan cara online melalui website [2]. dilakukan melalui smartphone Android dengan Menurut hasil survey 2017 oleh Asosiasi memanfaatkan Bluetooth. Google Voice Command Penyelenggara Jasa Internet Indonesia (APJII), Recognition System digunakan sebagai penterjemah perkembangan penggunaan internet di Indonesia juga voice command menjadi teks dengan bantuan aplikasi mengalami peningkatan dari tahun sebelumnya. Pada AMR_Voice pada smartphone, yang selanjutnya data tahun 2017 tercatat 54,68\% pengguna internet di string teks tersebut dapat diolah oleh Mikrokontroler Indonesia, atau 143,26 juta jiwa dari total populasi Arduino Uno untuk menyalakan atau mematikan penduduk Indonesia [3]. Bahkan pengggunaan peralatan elektronik seperti lampu dan kipas angin. komputer dimasa akan datang mampu mendominasi Dengan menggunakan Bluetooth, komunikasi data pada pekerjaan manusia dan mengalahkan kemampuan sistem ini memiliki jangkauan 10 meter untuk dapat komputasi manusia seperti mengontrol peralatan menyalakan lampu dan kipas meskipun terhalang elektronik dari jarak jauh menggunakan konektivitas tembok [8].

internet, atau dikenal dengan konsep IoT (Internet of Things) [4]. Dengan memanfaatkan konsep IoT (Internet of Things memungkinkan pengendalian daya listrik seperti menyalakan dan mematikan lampu dapat di lakukan dengan jangkauan yang luas.

Penelitian pengendalian perangkat Keamanan Pintu Pagar Otomatis Menggunakan Voice Recognition ditulis oleh Ashar Seppiawan, dkk. Penelitian tersebut di latar belakangi oleh maraknya tingkat kejahatan dan semakin canggihnya sistem dalam membobol atau 
merusak sistem keamanan yang berupa kunci konvensional. Voice Recognition di aplikasikan menggunakan modul EasyVR, dimana tingkat keberhasilan cukup rendah dengan presentase $10,4 \%$ jika menerima perintah suara dari orang yang berbeda. Sedangkan memiliki tingkat keberhasilan yang tinggi sebesar $88 \%$ apabila pengambilan suara dilakukan oleh orang yang melakukan sampling suara [9].

Dari semua penelitian tersebut memberikan sebuah inspirasi untuk melakukan penelitian mengenai pengendalian perangkat listrik menggunakan perintah suara. Sehingga diharapkan penggunaan daya listrik dapat lebih efektif dan efisien. Tujuan dari pembuatan prototype alat pengendali lampu dengan perintah suara menggunakan Arduino Uno berbasis web yaitu menciptakan inovasi baru untuk memberikan kemudahan dalam pengendalian lampu tanpa batasan jarak dengan memanfaatkan konektivitasi internet, serta pengendalian lampu yang lebih praktis dengan menggunakan perintah suara.

Metode pengembangan sistem pada perancangan alat pengendali lampu dengan perintah suara menggunakan Arduino Uno berbasis web yaitu menggunakan metode Prototype. Prototype merupakan metode yang cocok digunakan dalam pembuatan atau pengembangan suatu sistem maupun alat. Metode prototyping merupakan solusi cepat dan taktis pada sebuah pendekatan berbasis rekayasa (engineering) untuk merancang suatu produk. Pendekatan Prototyping adalah proses iterative yang melibatkan hubungan kerja yang dekat antara perancang dan pengguna [10]. Metode prototyping memungkinkan pengembang dan pelanggan untuk saling berinteraksi. Pendekatan Prototyping melewati tiga proses, yaitu Listen to Customer (Pengumpulan kebutuhan), Design and Build Prototype (Perancangan dan Pengembangan), Test Drives and Evaluation (Uji coba dan Evaluasi Prototype).

\section{Metode Penelitian}

Metode perancangan alat yang digunakan dalam penelitian adalah menggunakan metode prototype. Adapun tahapan perancangan dan menggunakan metode prototype meliputi tiga tahapan yaitu Listen to Costumer (Pengumpulan Kebutuhan), Design and Build Prototype (Perancangan dan Pembangunan Prototype), dan Test Drives and Evaluation (Uji Coba dan Evaluasi) [11].

\subsection{Listen to Costumer (Pengumpulan Kebutuhan)}

Pada tahap Listen to Costumer (Pengumpulan Kebutuhan), peneliti menggali permasalahan dan solusi yang dibutuhkan costumer dengan melakukan wawancara, studi literatur, dan kuisioner. Selanjutnya peneliti mulai mempersiapkan kebutuhan pada suatu sistem yang akan dibangun.

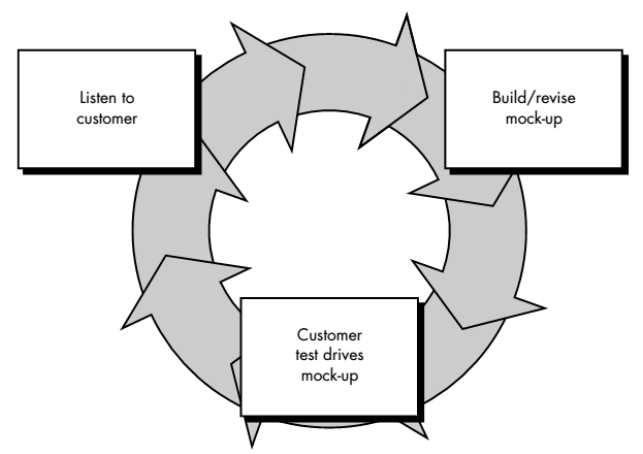

Gambar 1. Prototype model

Peneliti menemukan kendala yang dialami oleh pengguna lampu bahwa pengendalian lampu tidak dapat dikendalikan pada jarak jauh. Dengan adanya permasalahan tersebut, maka peneliti berinisiatif untuk membuat pengendali lampu yang dapat dikendalikan tanpa batasan jarak dengan memanfaatkan konektivitas internet dengan menggunakan Arduino uno berbasis $w e b$. Penggunaan input berupa perintah suara, membuat pengendalian lampu dapat dilakukan dengan lebih mudah dan praktis.

2.2. Design and Build Prototype (Perancangan dan Pembangunan Prototype)

Pada tahap Design and Build $h$ pada prototype. Dalam tahap perancangan, penulis mengidentifikasi kebutuhan guna membangun prototype yang diharapkan. Kebutuhan yang digunakan antara lain Arduino Uno sebagai mikrokontroler pengendali lampu, dan Speech to Text pada Web Speech API sebagai pemrosesan suara. Perancangan prototype berupa blok diagram seperti pada gambar 2.

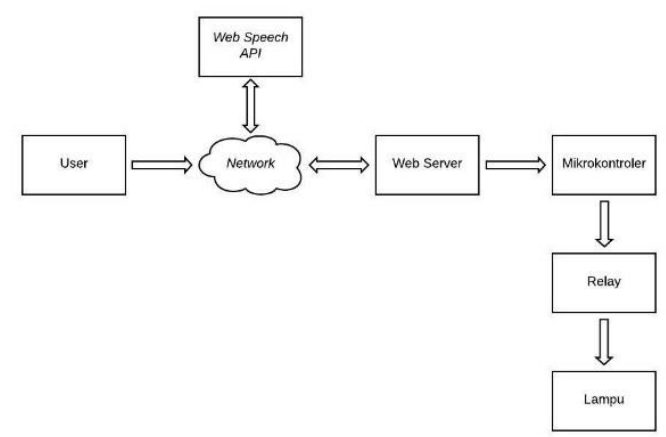

Gambar 2. Blok diagram pengendali lampu

Penjelasan dari blok diagram pada gambar 2 yaitu user dapat diartikan sebagai pengguna dengan menggunakan laptop, tablet ataupun smartphone. Kemudian user akan melakukan input berupa perintah suara untuk kendali lampu yang berupa menyalakan atau mematikan lampu. Dengan memanfaatkan speech to text pada Web Speech API, suara yang masuk 
dikonversi menjadi teks. Untuk mndapatkan akses yang di aliri tenaga listrik. Setelah selesai pada server Web Speech API pengguna harus menggunakan rangkaian hardware, pengguna selanjutnya melakukan koneksi internet sebagai perantara pertukaran data. proses pengendalian lampu dengan perintah suara pada Input yang berupa teks perintah suara selanjutnya browser Personal Computer (PC), maupun diolah menjadi kode angka ke server, dan akan di Smartphone.

respon oleh server dengan mengirimkan instruksi Pengendalian lampu dapat dilakukan dengan memberi switch on atau switch off berupa nilai hight atau nilai input berupa perintah suara pada halaman web yang low pada mikrokontroller Arduino Uno R3. Sesuai telah dirancang seperti pada Gambar 5.

dengan data yang diterima, mikrokontroller akan menjalankan relay untuk on atau off. Sedangkan perancangan flowchart diagram pada sistem pengendali lampu seperti pada gambar 3 .

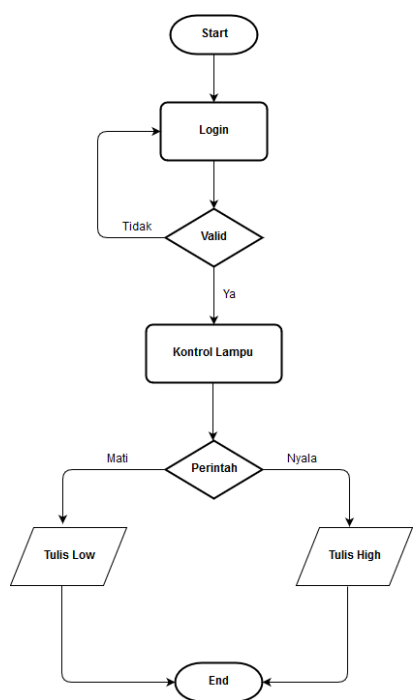

Gambar 3 . Flowchart diagram sistem pengendali lampu

\section{Lamp Control}

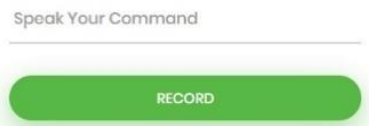

Gambar 5. Rancangan Web pada Pengendali Lampu dengan memberi input berupa perintah suara dengan menekan tombol "RECORD", selain dengan perintah suara, alternatif pengendalian lampu juga dapat dilakukan dengan input ketik keyboard.

\subsection{Test Drives and Evaluation (Uji Coba dan} Evaluasi).

Pada tahap Test Drives and evaluation (uji coba dan evaluasi) dilakukan uji coba dan evaluasi untuk mengetahui tingkat keberhasilan prototype yang Tahap setelah perancangan yaitu pembangunan dibangun. Uji coba dilakukan dengan memberi perintah prototype meliputi pembangunan hardware, dan suara sesuai dengan perintah yang sudah ditentukan di software. Pembangunan rangkaian hardware dalam sumber data seperti pada tabel 1.

berdasarkan arsitektur blok diagram sistem pengendali lampu hasil rancangan maka dibutuhkan rangkaian hardware berupa mikrokontroller menggunakan papan Arduino Uno R3 sebagai komponen utamanya yang kemudian dihubungkan pada rangkaian relay sebagai media switch elektronik lampu. Rangkaian hardware seperti pada Gambar 4.

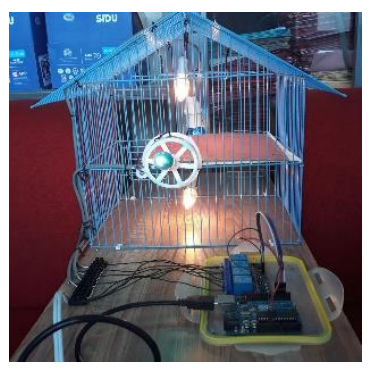

Gambar 4. Rangkaian Hardware Alat Pengendali Lampu

Tabel 1.Tabel Perintah Kendali Lampu dengan Suara

\begin{tabular}{lll}
\hline Lampu & Perintah ON & Perintah OFF \\
\hline Lampu 1 & Satu Nyala & Satu Mati \\
Lampu 2 & Dua Nyala & Dua Mati \\
Lampu 3 & Tiga Nyala & Tiga Mati \\
Lampu 4 & Empat Nyala & Empat Mati \\
Semua & Nyala Semua & Mati Semua \\
Lampu & & \\
\hline
\end{tabular}

Pengujian dilakukan dengan menguji pengaruh kecepatan internet dan pengaruh tingkat kebisingan ruang pada keberhasilan prototype. Kendali lampu dilakukan sebanyak 10x pada masing-masing perintah kendali lampu, Selain itu peneliti menguji kecepatan respon alat terhadap perintah suara

\section{Hasil dan Pembahasan}

Pemanfaatan Web Speech API pada prototype alat Langkah pertama yang dilakukan untuk menggunakan pengendali lampu dengan perintah suara menggunakan alat pengendali lampu yaitu menghubungkan rangkaian Arduino Uno berbasis web mengharuskan pengguna Arduino Uno R3 dan Relay ke komputer, dan mengaksesnya secara online, sehingga pengaruh menghubungkan steker yang telah dihubungkan dengan kecepatan internet dapat mempengaruhi tingkat keempat lampu pada rangkaian menuju stopkontak keberhasilan dalam mengontrol lampu. Peneliti 
membagi menjadi dua pengujian, yaitu pengujian pada kecepatan internet 9.9 Mbps dan 1.9 Mbps. Hasil pengujian pada tabel 2. Kendali lampu dilakukan sebanyak 10x pada masing-masing perintah kendali lampu.

\begin{tabular}{llll} 
& \multicolumn{3}{c}{$\begin{array}{c}\text { Tabel } \\
\text { 2. . Tabel Keberhasilan Prototype } \\
\text { pada Kecepatan }\end{array}$ Internet 9.9 Mbps } \\
\hline Lampu & $\begin{array}{l}\text { Kendali } \\
\text { Lampu }\end{array}$ & Keberhasilan & Kegagalan \\
& ON & 7 & 3 \\
Lampu 1 & OFF & 9 & 1 \\
& ON & 9 & 1 \\
Lampu 2 & OFF & 9 & 1 \\
& ON & 8 & 2 \\
Lampu 3 & OFF & 8 & 2 \\
& ON & 8 & 2 \\
Lampuo 4 & OFF & 9 & 1 \\
Semua Lampu & ON & 9 & 1 \\
& OFF & 10 & 0 \\
Total Hasil & & 86 & 14 \\
\hline
\end{tabular}

Dari hasil tabel 2. pengujian keberhasilan terhadap pengaruh kecepatan internet 9.9 Mbps mendapat keberhasilan sebesar $86 \%$ dan kegagalan sebesar $14 \%$. Selanjutnya pengujian terhadap pengaruh kecepatan internet pada 1.9 Mbps, hasil pengujian seperti pada tabel 3 .

\begin{tabular}{llll} 
& $\begin{array}{c}\text { Tabel } \\
\text { 3. Tabel Keberhasilan Prototype } \\
\text { pada Kecepatan Internet 1.9 Mbps }\end{array}$ \\
\hline Lampu & Kendali & Keberhasilan & Kegagalan \\
& Lampu & & \\
\hline Lampu 1 & ON & 5 & 5 \\
& OFF & 6 & 4 \\
Lampu 2 & ON & 7 & 3 \\
& OFF & 7 & 3 \\
Lampu 3 & ON & 8 & 2 \\
& OFF & 7 & 3 \\
Lampuo 4 & ON & 6 & 4 \\
& OFF & 7 & 3 \\
Semua Lampu & ON & 6 & 4 \\
& OFF & 6 & 4 \\
Total Hasil & & 65 & 35 \\
\hline
\end{tabular}

Dari hasil tabel 3. uji keberhasilan terhadap pengaruh kecepatan internet 1.9 Mbps mendapat keberhasilan sebesar $65 \%$ dan kegagalan sebesar $14 \%$. Dari hasil pengujian tersebut, maka dapat disimpulkan masuk, dan mengakibatkan rendahnya tingkat bahwa kecepatan internet mempengaruhi tingkat keberhasilan. Sebaliknya, semakin rendahnya tingkat keberhasilan pada prototype pengendali lampu dengan kebisingan atau kategori tenang, maka sistem semakin perintah suara menggunakan Arduino Uno berbasis jelas dan mudah untuk menerima perintah yang ucapkan web. Semakin besar kecepatan internet yang digunakan oleh pengguna. Selain pengujian pada pengaruh maka semakin tinggi tingkat keberhasilan, dan semakin kecepatan internet dan tingkat kebisingan ruang, juga lambat kecepatan internet yang digunakan maka dilakukan pengujian guna mengetahui waktu respon alat semakin kecil tingkat keberhasilan. Selain pengujian terhadap perintah suara yang masuk. Hasil pengujian terhadap kecepatan internet, peneliti juga menguji terdapat pada tabel 6.

pengaruh tingkat kebisingan ruang yang dikategorikan menjadi dua, yaitu tingkat kebisingan ruang sebesar Dari hasil pengujian pada tabel 6 waktu respon alat pada $34.5 \mathrm{~dB}$ atau kategori tenang, dan tingkat kebisingan kecepatan internet 9.9 Mbps yaitu 2.01 detik, pada ruang $62 \mathrm{~dB}$ atau kategori ramai. Hasil pengujian pada kecepatan internet $1.9 \mathrm{Mbps}$ yaitu 2.50 detik, sedangkan tingkat kebisingan ruang $34.5 \mathrm{~dB}$ dapat dilihat pada pada kebisingan ruang $34.5 \mathrm{~dB}$ yaitu 2.02 dB, tabel 4 .
Tabel 4. .Tabel Keberhasilan Prototype pada Kebisingan Ruang 34.5 dB

\begin{tabular}{llll}
\hline Lampu & Kendali Lamp & Keberhasilan & Kegagalan \\
\hline Lampu 1 & ON & 7 & 3 \\
& OFF & 9 & 1 \\
Lampu 2 & ON & 9 & 1 \\
& OFF & 9 & 1 \\
Lampu 3 & ON & 8 & 2 \\
& OFF & 8 & 2 \\
Lampuo 4 & ON & 8 & 2 \\
& OFF & 9 & 1 \\
Semua Lampu & ON & 9 & 1 \\
Total Hasil & OFF & 10 & 0 \\
\hline
\end{tabular}

Dari hasil tabel 4. pengujian keberhasilan terhadap kebisingan ruang $34.5 \mathrm{~dB}$ mendapa keberhasilan sebesar $86 \%$ dan kegagalan sebesar $14 \%$

Selanjutnya pengujian terhadap pengaruh kebisingan

Tabel 5. .Tabel Keberhasilan Prototype pada Kebisingan Ruang $62 \mathrm{~dB}$

\begin{tabular}{llll}
\hline Lampu & Kendali Lamp & Keberhasilan & Kegagalan \\
\hline Lampu 1 & ON & 7 & 3 \\
& OFF & 8 & 2 \\
Lampu 2 & ON & 8 & 2 \\
& OFF & 9 & 1 \\
Lampu 3 & ON & 8 & 2 \\
& OFF & 8 & 2 \\
Lampuo 4 & ON & 7 & 3 \\
\multirow{5}{*}{ Semua Lampu } & OFF & 9 & 1 \\
\multirow{2}{*}{ Total Hasil } & ON & 7 & 3 \\
& OFF & 8 & 2 \\
\hline
\end{tabular}

Dari hasil tabel 5. pengujian keberhasilan terhadap pengaruh kebisingan ruang $62 \mathrm{~dB}$ mendapat keberhasilan ebesar $79 \%$ dan kegagalan sebesar $21 \%$.

menyimpulkan bahwa tingkat kebisingan juga mempengaruhi tingkat keberhasilan pada prototype pengendali lampu dengan perintah suara menggunakan Arduino Uno berbasis web. Semakin besar tingkat kebisingan maka semakin sulit sistem menerima ucapan pada kebisingan ruang $34.5 \mathrm{~dB}$ yaitu $2.02 \mathrm{~dB}$
sedangkan pada kebisingan ruang $62 \mathrm{~dB}$ yaitu
2.21 detik. 
Tabel 6. Tabel.Hasil Waktu Respon Alat

\begin{tabular}{|c|c|c|c|c|}
\hline Perintah & $\begin{array}{l}\text { Internet } \\
9.9 \\
\text { Mbps/ } \\
\text { detik }\end{array}$ & $\begin{array}{l}\text { Internet } \\
1.9 \\
\text { Mbps/ } \\
\text { detik } \\
\end{array}$ & $\begin{array}{l}\text { Ruangan } \\
34.5 \\
\text { dB/detik }\end{array}$ & $\begin{array}{l}\text { Ruangan } \\
62 \\
\text { dB/detik }\end{array}$ \\
\hline Satu Nyala & 2.61 & 2.42 & 2.24 & 2.28 \\
\hline Satu Mati & 2.67 & 2.03 & 1.77 & 2.48 \\
\hline Dua Nyala & 1.12 & 2.10 & 1.96 & 2.94 \\
\hline Dua Mati & 2.02 & 3.10 & 2.49 & 1.38 \\
\hline Tiga Nyala & 2.00 & 1.96 & 1.44 & 1.57 \\
\hline Tiga Mati & 1.76 & 1.96 & 2.49 & 1.76 \\
\hline Empat Nyala & 2.30 & 2.10 & 1.77 & 1.96 \\
\hline Empat Mati & 2.61 & 2.93 & 2.62 & 1.76 \\
\hline Nyala Semua & 1.77 & 3.33 & 2.02 & 3.19 \\
\hline Mati Semua & 1.24 & 3.08 & 1.44 & 2.80 \\
\hline $\begin{array}{l}\text { Rata-rata } \\
\text { waktu }\end{array}$ & 2.01 & 2.50 & 2.02 & 2.21 \\
\hline
\end{tabular}

\section{Kesimpulan}

Berdasarkan hasil pengujian dan Analisa maka dapat disimpulkan bahwa prototype pengendali lampu dengan perintah suara menggunakan Arduino uno berbasis web memiliki tingkat keberhasilan yang berbeda-beda, dipengaruhi oleh tingkat kecepatan internet yang digunakan, dan pengaruh tingkat kebisingan ruang saat memberi input perintah suara. Pada kecepatan internet 9.9 Mbps memiliki tingkat keberhasilan 86\%, sedangkan pada kecepatan internet 1.9 Mbps memiliki tingkat keberhasilan 65\%. Semakin besar kecepatan internet yang digunakan maka semakin tinggi tingkat keberhasilan, dan semakin lambat kecepatan internet yang digunakan maka semakin kecil tingkat keberhasilan. Sedangkan pada tingkat kebisingan ruang $34.5 \mathrm{~dB}$ memiliki tingkat keberhasilan sebesar $86 \%$, sedangkan pada tingkat kebisingan ruang $62 \mathrm{~dB}$ memiliki tingkat keberhasilan $72 \%$. Semakin besar tingkat kebisingan maka semakin sulit sistem menerima ucapan perintah karena terlalu banyak suara/kebisingan yang masukdan mengakibatkan rendahnya tingkat keberhasilan. Sebaliknya, semakin rendahnya tingkat kebisingan atau kategori tenang, maka sistem semakin jelas dan mudah untuk menerima perintah yang ucapkan oleh pengguna. Saran penelitian selanjutnya yaitu pengendali lampu dapat diintegrasikan dengan kamera pemantau atau sensor pendeteksi cahaya untuk mempermudah dalam pengendalian lampu apakah sudah benar-benar menyala atau mati.

\section{Daftar Rujukan}

[1] Wink, "A Simpler Way To Smarter Home," Blog.wink.com, 2017. Available: http://blog.wink.com/winkblog?category=News. [Accessed: 31-Jan-2019].

[2] Kurniawan, "PURWA RUPA IoT ( Internet of Things ) Kendali Lampu Gedung," Universitas Lampung, 2016.

[3] APJII, "Penetrasi \& Perilaku Pengguna Internet Indonesia 2017, , 2017.

[4] A. Junaidi, "Internet of Things , Sejarah , Teknologi Dan Penerapannya: Review Internet of Things , Sejarah , Teknologi Dan Penerapannya: Review," Jitter, vol. I, no. 3, pp. 62-66, 2015.

[5] B. S. Kumar, "Natural Language Processing Based Home Automation System Using Smartphone And Aurdino Microcontroller Board," IJCESR, vol. 4, no. 11, pp. 73-77, 2017.

[6] P. Saputra, "Smart Home Dengan Speech Recognition Melalui Bluetooth Berbasis Android," J. Elektron. Pendidik. Tek. Elektron., vol. 7, no. 2, pp. 38-55, 2018.

[7] D. Andyka and M. C. Anwar, "Rancang Bangun Aplikasi Android Pengendalian Smarthome Menggunakan Perintah Suara," SEHATI, pp. 48-51, 2017.

[8] A. W. Dani, A. Adriansyah, and D. Hermawan, "Perancangan Aplikasi Voice Command Recognition Berbasis Android Dan Arduino Uno," J. Teknol. Elektro, vol. 7, no. 1, pp. 11-19, 2016.

[9] A. S. N, Nurussa'adah, and P. Siwindarto, "Sistem Keamanan Pintu Pagar Otomatis Menggunakan Voice Recognition," $J$. Mhs. Teub, vol. 2, no. 6, pp. 1-6, 2014.

[10] Y. A. Prasetyo and N. Ambarsari, "Pengembangan Web ECommerce Bojana Sari menggunakan Metode Prototype," $e$ proceeding Eng., vol. 2, no. 1, pp. 1042-1056, 2015.

[11]R. S. Pressman, Software Engineering - a Practitioner's Approach, Eighth edi. Mc Graw Hill, 2016. 